\title{
初期小石川後楽園における眺望行為に関する研究
}

\section{A Research on an Act of Viewing in Koishikawa Koraku-en Garden's Early Days}

\author{
李偉*
}

Wei LI

\begin{abstract}
Former studies on Koishigawa Koraku-en garden have traced its historical transformation and have obtained good outcomes in investigating its design, and the arrangement and characteristic of its parts. However, these researches have been concentrated on the internal landscape of the garden and the examination of the idea aspect that it bears. The location of Korakuen and the scenery viewing from the garden have rarely been discussed. Whether or not there is viewing scenery is not only a matter that concerns the appreciations of the garden but also exerts influences on the usage of the garden and the owner's view towards the garden. Without the elucidation of this issue, I suppose that on no account we could properly evaluate the structure and design of Koraku-en. Based on documentary records, especially historical sources written in Chinese, this study examines the location of Koraku-en and discusses whether or not there were acts of viewing towards the outside of the garden and intentional uses of borrowed scenery (Shakkei) in Koraku-en's early days.
\end{abstract}

Keywords: Koishikawa Koraku-en Garden, an act of viewing, Borrowed Scenery (Shakkei) キーワード : 小石川後楽園, 眺望行為, 借景

\section{1. 研究の目的と対象}

小石川後楽園は江戸初期に成立した典型的な回遊式庭園である。 大泉水を中心にして, 大堰川, 白糸滝など日本の名所をモチーフ としたデザインや，西湖堤や円月橋など中国趣味のデザインを園 内各所に取入れ, それまでの日本庭園の構成要素を集大成した庭 園之いえよう。江戸初期の大名庭園の一つとして著名であり, 他 の大名庭園に多大の影響を及ぼした。

従来の後楽園研究は, 同園の歴史的変遷をたどり, 意匠や局部 の配置・特徵などの究明に成果をあげた ${ }^{1)}$ 。しかし, それらは庭 園内部の景観之, それがあつ思想的側面の検討に集中し, 後楽園 の立地や庭園からの眺望景観は, ほとんど重要視されてこなかっ た。そこから導かれた後楽園像はかなり閉鎖的なあのであった。 本研究は, 後楽園の眺望景観に焦点を絞り初期史料の分析にも之 づき，再検討を試みるあのである。

庭園と眺望との関係について, 本中はのちの借景にいたる前の 段階を「眺望行為」として詳しく分析し ${ }^{2)}$ ，また，飛田は借景に ついて論じ,「厳密な定義はむずかしい」3) としながら，借景を 「庭園の構成要素々の関係が意識されている背景」4) と定義した。 本研究は, こうした先行研究をふまえ, 借景とは「庭園外の景観 を, たんなる背景ではなく, その庭園の重要な構成要素として利 用する行為, またその手法を指す」と考えるが, この借景に先行 する眺望行為を, 庭園外の景観を無意識に眺める「たんなる眺望 行為」之，庭園外の景観を意識的に評価する「意識的な眺望行為」 に分けて論述を進めるものである。

元禄之享保年間の後楽園をめぐる一連の大改造の記録以降, 後 楽園の眺望景観が記されるようになったと従来考えられてきた ${ }^{5)}$ 。 それも眺望を重要視する意味ではなく, 大改造から導かれた悪影 響として認識された。眺望景観の有無は庭園の鑑賞法にかかわる 問題だけではなく, 庭園の利用法, また持ち主の庭園観にも影響 を及ぼしたところであり，これを補ってみなくては後楽園の地割 や意匠は決して正当に評価できないであろう。眺望景観の検討は, 江戸時代の庭園像を掴むむう一つの重要な鍵だと考えている。 本研究は文献史料, 特に漢文史料をもとに初期後楽園の立地を
含めた変遷を考察し, 園外の眺望行為があったかどうか, そして それは厳密な意味で借景となりえたから゙うかを検討するあのであ る。

\section{2. 史料分析}

小石川後楽園は寛永 6 年 (1629), 二代将軍徳川秀忠が水戸徳 川家の初代藩主頼房に 76,699 歩（約 $253,074 \mathrm{~m}^{2}$ ）に及ぶ大規模な 敷地を宅地として与えたことにはじまる ${ }^{6)}$ 。後楽園の立地に関し て『水戸紀年』（1828）は小石川邸地の前身について記してい る ${ }^{7)}$ 。ここはもと本妙寺と吉祥寺の境内であったが, 両寺院は他 所に移転されてその跡地が水戸藩に与えられた。寺院の移動も惜 しまず，望ましい地所が確保された上で，大規模な造園活動が行

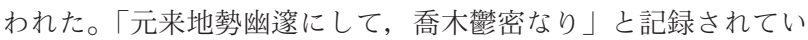
ることから, 後楽園の雾囲気に関して従来の研究のほとんどはこ の記述に影響され，園内の「深山幽谷」「「市中の山林」の意境だ けが強調されてきた ${ }^{8)}$ 。

『水戸紀年』は後楽園成立から 200 年あまりを経てから編集さ れたもので，時代状況之政治状況を背負った記述がなされている と考えられ，簡単に信用できるかどうかは疑問である。確かに寺

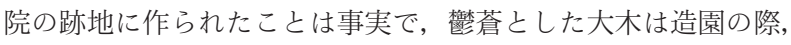
そのまま利用されて残ったのかむしれない。だが，初期後楽園の 景観の検討は，園内の景観だけで充分であろうか。

初期後楽園についてその当時記された文献である林道春の「小 盧山記」には眺望景観の記述があらわれる ${ }^{9)}$ 。

「小盧山記」は寛永 17 年（1640）3 月, 頼房が林羅山を庭園 に召し，庭園の築山に命名せしめた記録である。羅山は小盧山と 名づけ, 小盧山の三字を書き,「小盧山記」を残した。中国の名 勝地盧山を意識しながら, また中国の古典『神仙伝』や『荘子』, 『論語』を自由に駆使し, 目の前のすばらしい庭景と水戸侯の仁 徳を称えた文章になっている。林羅山は江戸初期の幕府の儒官之 して知られ, 漢詩文の素養が高かった。文章は古典を多用してお り, また大胆な文学的修飾も加えている。そのため, 小盧山から 実際どれほど園外の景観を見渡せたかは確定しがたいが，ここで

*総合研究大学院大学文化科学研究科 
重要なのは, 眺望を感じさせる記述の存在である。小盧山に登れ ば「千里海山の佳景」, すなわち周囲の景観の広がりを眺望でき たとの表現は誇張を伴うことを割り引いて考える必要がある。し かし,「千里海山」といった遠望を意識した表現, 「佳景」という 景観のすばらしさを意図した表現があることから, 光圄時代に小 盧山からの遠望が，それなりの絶景として認められていたと考え たい。

「小盧山記」から 22 年, 二代光图の命により国史編纂の事業 に携わった林羅山の三男林黛峯が園遊の記録を残している。それ は寛文 2 年（1662） 10 月ょり，同 12 年（1672）12月に至る 10 年間, 䳎峯が日々の記録として書き続けた『国史館日録』に見い だせる。国史館に打ける修史事業関係の記事を中心に記載された あのだが，そのほか，史館の庭園で酒を飲み，詩会を開き，花見 をするなど当時の文人たちの交遊, 君主水戸光图などとの接触, 政治，学問に関する論議などの記録も見られる。『国史館日録』 の中には, 後楽園について書かれた箇所が三筒所ある。

最初の記録は寛文 5 年 (1665) 6 月 17 日の記述である ${ }^{10)}$ 。この 日，侪峯は光图に召されて，息子と門人とと屯に水戸邸を訪れた。 光图はたいへん喜んで, 黛峯たちを誘って園中を逍遥した。「周 回寛広, 池有り林有り, 池上に長橋を架し, 橋下に舟有り, 喬木 茂草千萬章なり」11) と黛峯は記す。「細徑を挙がりて山に上る。山 に二堂有り, 其の一は夷斉堂と号して半腹に在り, 其の一は絶頂 に在りて至徳堂と号し, 泰伯を祭りて云云, 」続く。夷斉堂と 至徳堂は後世の得仁堂と考えてょ(12)。当時光图は伯夷・叔斉の 高徳を慕ってこの堂を建てたのである。得仁堂は小盧山のすぐ近 くの山に位置しているとの説むあるが ${ }^{13)}$, 上掲の文章から見るか ぎり, 細い道をたどって上った山を小盧山と称していると思われ る。

ここで重要なのはつづけて「其の余の境致は暫く置きて言わず, 遠望絶景勝げて計ふべからず ${ }^{14)}$ と述べているところである。遠 望の絶景は他の境致から突出した存在として取り扱われているの である。築山に上り, 園中の美景はもちろん楽しんだであろうが, 特に遠望の絶景を強調したことは重要である。光图時代から, す でに小盧山から見た園外の遠望景観を称えるようになっている。 またこの文章から, 光目が常に後楽園に儒者たちを招いて, 史書 の編修などの相談のほか, 園遊させ, 詩も作らせるなど, 一大趣 味人としての姿も見せたことがうかがえる。

また，寛文 8 年（1668）４月８日の条 ${ }^{15)}$ と寛文 9 年（1669） 5

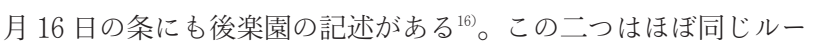
卜での園遊であり, 水戸邸一儒者を招待し, 饗宴のあと園遊させ, 詩宴の会を催したもので, 当時の庭園の雾囲気が偲ばれる記録で ある。

「園中山あり, 池あり, 船あり, 橋あり, 嘉木奇嚴備わらざる なし。径路は迢迢として村野の如く, その間に清水長流し, 璇瀑 は迸出し, 水車は水を挽いて回転する」, と当時の後楽園の光景 が描写されている。

水戸侯は自ら先導して小盧山を登った。この時期の小盧山の姿 について「山下に閣有り, 其間に㟴㦑有り, 其路細くして斜長な り」すなわち山の下に閣があり, その間に高く険しく算え立つ岩 山があり, その道は細くして斜めに長いと記されている。光图自 ら先導して, 儒者たちと一緒に小盧山を登っていることから, こ の時代の小盧山の景色にかなり自信をむっていたことが想像でき る。この時代, 小盧山に登ることが園遊のメインルートに含まれ ていたことは疑いの余地がないであろう。園遊のあと, 皆に詩を 求め, 歌を詠みあうことも光图の園遊会の慣例になったことがう かがえる。

「小盧山記」は頼房時代の後楽園の記録であり，この時代にお いて小盧山の上から見る眺望景観が賞賛され, その記録がすでに
林羅山によって残されたことがわかる。羅山の三男の林偣峯の 『国史館日録』のなかに書かれた光图時代の後楽園鑑賞記に至っ ては, 毎回小盧山を登り, 眺望するのが慣例になって, 後楽園見 学のメインルートになったことが推測できる。

次にほぼ同時代に書かれた『遊後楽園賦并序』(1669) をみて みよう。

「斯園殆ど天下に於いて甲なるかな」17) つまり後楽園の景観が 天下無双の美景だと絶賛されている。筆者朱舜水は明の遺民で日 本に亡命し，儒者としてすでに碩学の譽が高かったが，更に多芸 多能の実際家として優秀な技能を有していた。寛文 5 年光图は朱 舜水を江戸に招致し，自ら弟子の礼を執って厚遇した。その報恩 として, 朱舜水は水戸藩の種々の土木建築事業に参画して妙技を 振るった。この後楽園記は, 主君に対する感謝の気持ちにあふれ ている。「遊後楽園賦并序」は光圀時代の後楽園を理解するため 重要な文献である。

光图は饗宴の前にまず儒者たちを園遊させた。朱舜水は自ら山 道を登り，橋を渡って，閣に入った。そこで「重霄饗答し，千門 を下瞰す」戛 すなわち景色はここで豁然と開けた。「重霄」は広い 空のことで，「千門」は「多くの家。千家」の意味である ${ }^{19)}$ 。お そらく広々とした空を仰いで, 街中の民家を俯瞰したのだろう。 天と地はここで一体になり，遠望の絶景はこの上ないと，朱舜水 は絶賛したのであった。

この文章はまた光圀主催の饗宴において，余興の舟遊が行われ た模様む描いている ${ }^{20)}$ 。

舟子は船を橋畔に繋ぎ，朱舜水らの脇を支えて舟に乗せた。朱 舜水は「丹丘」(『楚辞』にいう仙人の住む丘）に目を凝らし，池 を三周したところで二編の詩を作った。二編目で「天は高い山を 作ったが, 実は人の力によって模倣することができる」と詠って いる。これはつまり築山のことである。舟は橋の傍から漕ぎ出し た。この橋は「長橋」のことを指している。光图はよく儒者たち を集め, 宴会を催した。自慢の庭園を鑑賞させるのも藩主のもて なしの一環になる。歩くだけではなく, 舟を出して, 大泉水を周 遊し, 酒を飲みながら, 景色を鑑賞し叙情の詩を作るのは園遊の 楽しみかたであろう。舟から見えたのは「丹丘」「疊䛿」であっ た。「疊镉」という言葉は「かさなった山」と解釈できる柿。「遙 指」であるから離れたところの山を指している。したがって，つ ぎつぎに重なる山なみを遥かに眺めたと解釈できる。

後楽園の景況を描いたもっとも古い図面に「水戸様江戸御屋敷 御庭之図」(図 1 ) がある。絵図の成立年代は定かではないが, 吉永義信は宝永年間（1704-11）よりやや遡るとしている22)。絵 図に「ホクロク堂」と称する建築物が松原近くに存在する。「木 クロク堂」は福禄堂であって, 元禄 16 年 (1703) の大地震で崩 壊し, その後再建されなかったのであるから, 絵図は少なくとあ 元禄 16 年を下らないものと考えられる。宝永焼失までの後楽園 は安定した時期であり, 光图によって完成された後, 大きな変化 がなかったことが想像できる。徳川綱條（三代）は元禄 3 年 （1690）光图の退隐により襲封し享保 3 年（1718）に薨去した。 この図はその間の状態を描いた鳥瞰図風の絵図であって, 後楽園 を図化した最初の資料といえる。測量術とその表現法がまだ未完 成な時代の図面であるから，現代的な意味での「正確さ」には欠 けるが, 当時の後楽園の地割と各局部の位置とを概略で明示する きわめて重要な資料であることは疑いえない。後楽園に関するこ の時代の他の文献と比較対照する価值がある。

この中で「長橋」と記された木橋は，大泉水の中央を南北に横 断していた。橋には西方に長方形の栈が張り出しており, いわゆ る雁歯橋である。橋台に巨大な根府川石が用いられていた。橋の 近くに中島がある。中島には老樹, 大石があり, 社が祀られてあっ た。長橋は大泉水を横断していて, 舟がくぐれる部分も設けられ 
ていたらしい。光图は邸内にあった史館（彰考館，『大日本史』 の編纂所）の儒者たちをここに集め，月見の詩宴を張ることもあ り，ここから眺めた庭園の風景は絶勝であったという ${ }^{23)}$ 。「水戸 様江戸御屋敷御庭之図」から見る之橋の西側, 橋台の真正面加ら 小盧山が見られる。清水堂が立つ山も見られ，朱舜水の詩の中の 「疊镉」は小盧山を含む山之解したい。(図 2 )

また最北部に庭園の背景をなすと思われる一連の山「見越山」 が描かれている。「見越山」と庭園との間に切通しと「長屋」が ある。江戸初期の後楽園では, 大泉水から望む見越山は庭園の背 景をなしていたと考えられる24。

この時代の見越山を後楽園に従属する別園之みたのは田村剛氏 だが25)，これは園遊にとって大事な景であり，単に別園といって 済ませることはできないであろう。寛政期には橋がなかった時期 ああったようだが, 見越山の地域は後楽園の大事な眺望景であっ たと見ておくのが良さそうだ。というのあ, ほとんどいつの時代 にも園の西北にあたる見越山の地域は切通しにより区別され，橋 によって連絡されていた26)。(図 3 )

光图の時代, 長橋から舟を出し, 大泉水から小盧山や見越山を 眺めることができたに相違ない，またそれらを鑑賞するのは園遊 の欠かせないルートだったであろう。

当日の宴会のメンバーのもう一人, 儒者である人見傳も後楽園 の様子を「春遊小石川邸後楽園記」に記した。園外の眺望景観は 人見傳の眼前にあるかのごとく展開した27)

人見傳は林黛峯に学んで, 光图に重用され，寛文 8 年 (1668) から史書編纂の大任を任された人物である。この日の来遊者が舟 遊を行い, 園遊のあと彼らに膳（食事）が供されたのは「遊後楽 園賦并序」の記述と同様だが, 眺望景観について人見傳は朱舜水 より詳しく記述している。引用(注 26 参照)の下線部「西に望め ば, 町の賑わいが目に入り, 往来も頻繁であり, 南に仰げば, 立 派な江戸城を拝見でき, 城の雉（たかがき）堞（ひめがき）は高

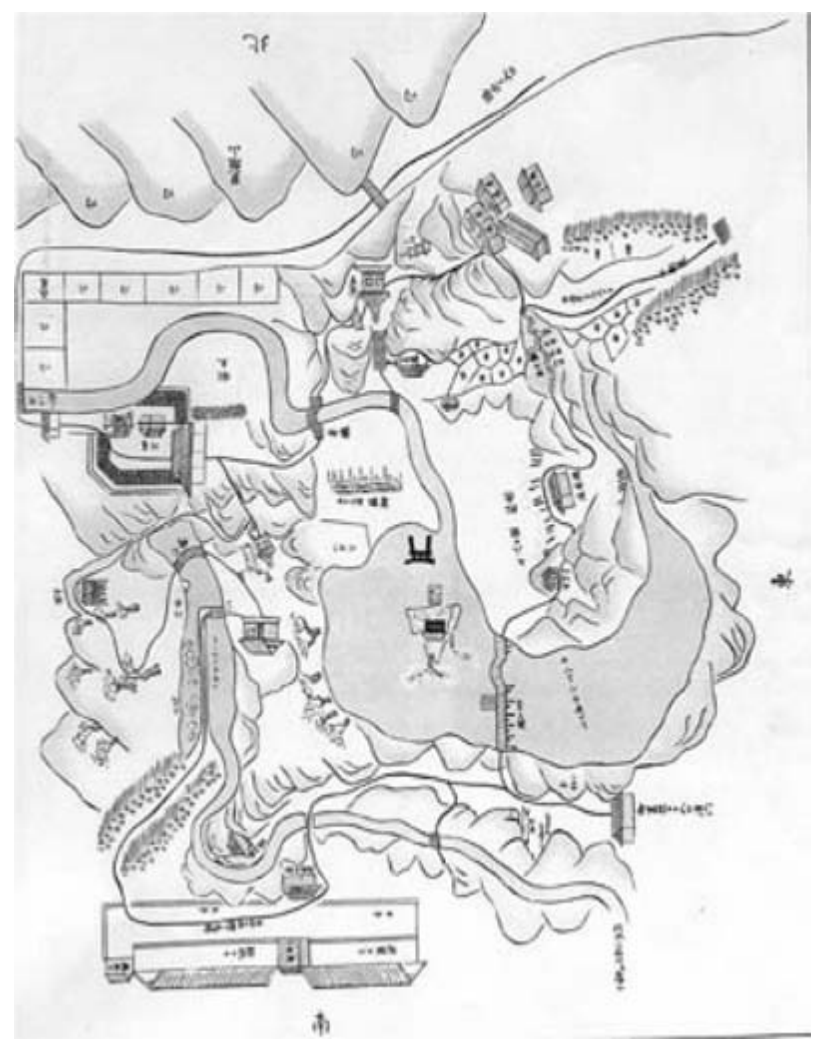

図-1「水戸様江戸御屋敷御庭之図」

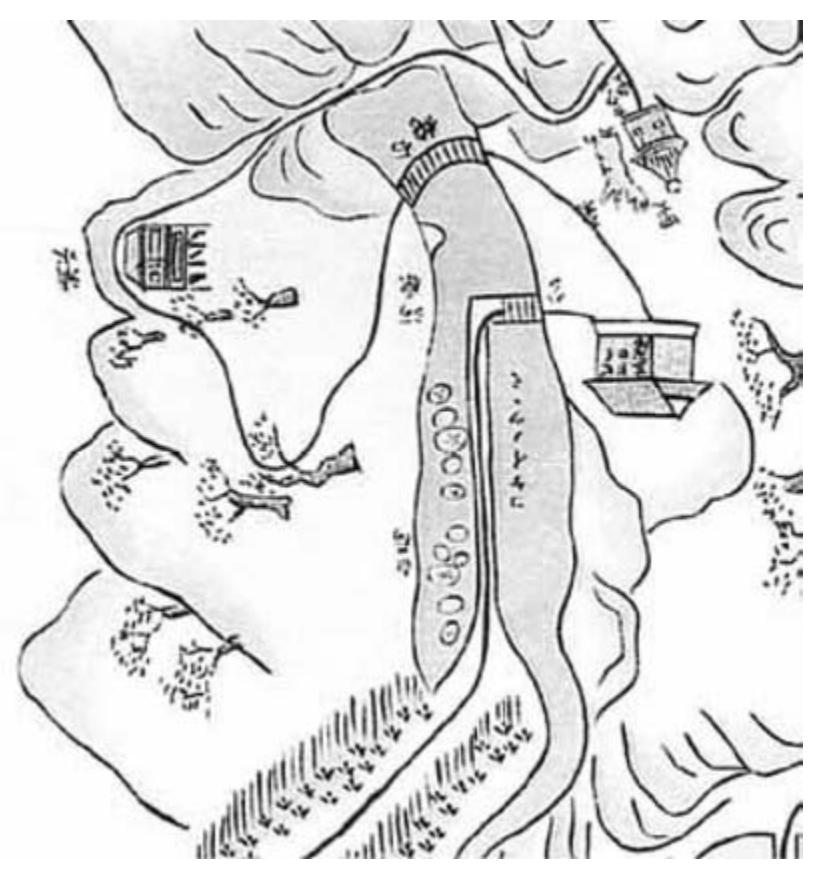

図－２小盧山付近（北を上にして掲載）

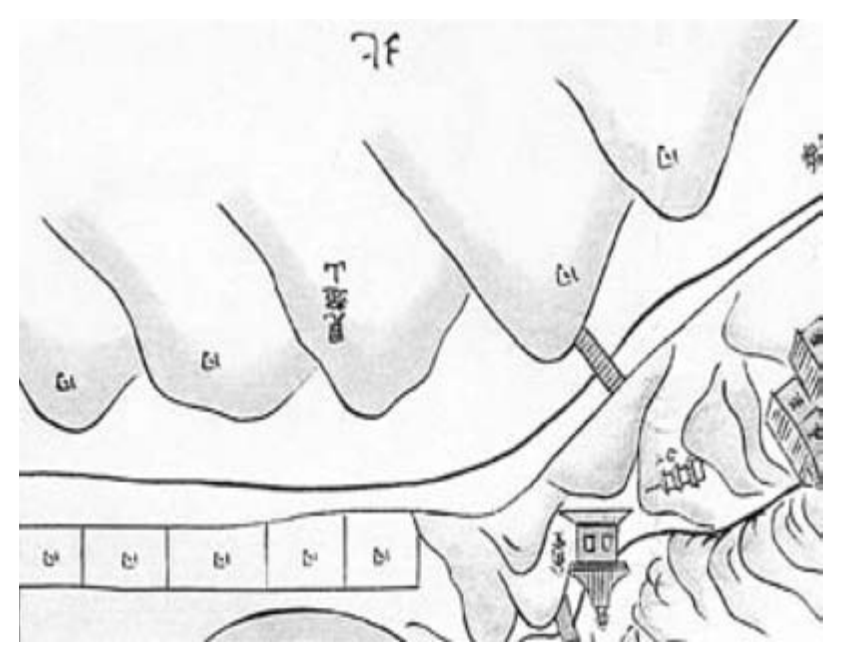

図－3 見越山付近（北を上にして掲載）

くて険しい」というょうに, 雄大な庭園感覚が表現されている。 当時の後楽園の絶景の中, 園内の景観だけではなく, 庭園外部の 城などの雄大な景観はもちろん，町の中の賑わいも目を楽しませ る賞賛の対象として認識されているのである。

次に元禄年間の重要な文献として, 辻雪洞の『東都紀行』があ げられる28)。

辻雪洞は『大日本史』の中心となる編集者として有名な知識人 である。彼の書いている『東都紀行』は江戸の案内書として諸大 名の邸宅，名勝旧跡を細かく記録している。後楽園に関する記録 は元禄 5 年（1692）に見学したときの遊園記である。ここで注目 すべきは，「富士のねを松の葉ごしに見渡せば，三保の浦浪㧍む かげにたつ」富士の峯を松の葉を通して見渡せば，三保の浦の浪 が眼前に浮かぶという歌が詠まれたことである。松の葉を通して, 遠く富士山を見たとの記述は眺望を考えるときたいへん重要であ る。光图もこの遠望の富士山は自分の庭の一つの絶景として, 非 
常に誇りをあったという。松の葉ごしに富士山が存分に見え, 遮 るものは一つもないほど，すばらしい景色だと絶賛している。当 時, 晴れた日に, 町中であ普通に見られた富士山は松の葉を通し て一層きれいに見えたことであろう。富士山の見えた場所は同じ 文献に，「清水の堂立たる山」と記された小盧山であろう。この ように後楽園はたんに園内の景を愛でるだけでなく, 周囲の景や 遠望む楽しむ庭園だったのである。

\section{3. 結論と展望}

初期小石川後楽園の景観を復元するための絵図, 文献史料は極 めて少ない。そこで従来あまり利用されなかった儒者たちによる 漢文史料に注目し，その解読によって初期の景観復元を試みよう とした。本稿では, これらの史料の分析を通じ, 初期後楽園の景 観を全体として理解するためには, 眺望景観に関する記録が無視 できないことを指摘した。

江戸前期の後楽園には寺院の跡地である影が濃厚に残っていた

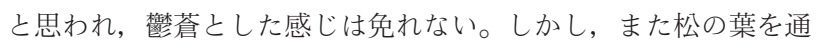
して見える富士山などが後楽園の絶景として認識されており，こ こには「意識的な眺望行為」が看取できる。初期の後楽園は深山 幽谷の景を中心としながら, 周囲の景観の眺望も重要な役割を果 たしたと思う。富士の高嶺はもちろん, 町の民衆の生活風景も初 期後楽園の眺望景観の一つとして鑑賞の対象になったことは興味 深い。頼房加光图に至る寛永寛文時代に後楽園は完成し, 綱條 の元禄中はまだ旧状がよく維持されていたと思われる。しかしこ の時代の後楽園にも園外の眺望行為があったとみてよい。第一の 眺望スポットは小盧山であったことは文献より推定できると考え る。

江戸中期以後, 眺望行為が強く現れるのは既往の研究の解釈と 矛盾しないが, 初期後楽園に眺望景観を意識的に愛でる意図がす でにあったと見るべきだろう。しかし，初期の後楽園に「意識的 な眺望行為」があったとしても, それはまだ厳密な意味での借景 とは言えない。江戸中・後期の後楽園に関して, どれほど眺望の 意識が働き, 庭園の重要な構成要素として利用したか, さらに分 析を進めたうえで考察する必要がある。今後の課題としたい。

\section{補注及び引用文献}

1）計見東山著並画（1909）：後楽園 全：東京育英社 田村剛（1929）：後樂園史：刀江書院

後楽園特輯 (1938) 7 月：造園研究 第二十五輯

吉永義信（1937）：小石川後楽園(名勝調查報告第三輯）：文部省 吉川需（1981）：小石川後楽園：郷学舎

2 ) 本中真（1994）：日本古代の庭園と景観：吉川弘文館

3 ）飛田範夫（1999）：日本庭園之風景：学芸出版社，182

4) 前掲書 3), 188

5 ) 額賀信興 （1736）：後楽園記事： 東京市史稿 遊園篇第一（1929） ：東京市役所，129,132,144

6 ) 水戸紀年（1828）：東京市史稿 遊園篇第一（1929）：東京市役所, 128

7 ) 是歳一公山水 7 好玉フ。因テ大奠公ヨリ小石川本妙寺

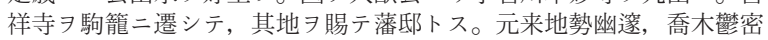
ソノ固有二據テ，徳大寺左衛門二命シテ假山水ヨ草創ス。

水戸紀年（1828）：重森三玲-重森完途（1974）：日本庭園史大系： 第 18 巻・江戸初期の庭（五）：社会思想社, 130

8 ）計見東山著並画（1909）：後楽園 全：東京育英社，2
白幡洋三郎（1997）：大名庭園一江戸の㗽宴：講談社，49

9 ）遠而近者望中千里海山之佳景朝而暮者臺上四時風雲之变態 林羅山（1640）：小盧山記：林羅山文集 巻第十六（1930）：弘文社, 182

10）申刻，依豫約携信 - 常 - 勝澄 - 友元詣水戸邸，謁参議君，君動喜色， 誘余輩逍遥園中, 周回寛広, 有池有林, 池上架長橋, 橋下有舟, 喬木 茂草千萬章，挙細徑上山，山有二堂，其一号夷斉堂在半腹，其一在絶 頂号至徳堂，(或名達徳）祭泰伯云云，……其余境致暫置不言，遠望 絶景不可勝計，既而君来，喤池畔亭子，招余輩探題賦詩，又聯句再巡， （後略）

山本武夫校訂（1997）：史料纂集 国史館日録 第一： 続群書類従 完成会, 114

11）前掲書 10)

12）藤島亥治郎（1938）：後楽園の建築：造園研究 第二十五輯， 25

13）吉永義信（1937）：小石川後楽園(名勝調查報告第三輯）：文部省，11

14）前掲書 10)

15）饗畢，参議遊園中，予従之，虎林等初見此園，園中有山有池有舟有橋， 嘉木奇嚴無不備焉，径路迢迢如村野，其間清水長流，嶡瀑迸出，水車 挽水回轉，虎林曰，如此佳境未曾見焉，頂有堂，号少盧山，是應故黄 門之求而先考記, 今猶存, 山下有閣, 其間有峵厳, 其路細而斜長, 参 議先導，虎林・春常・友元・伯元・正竹・狛庸及野傳等従之， 山本武夫校訂（1997）：史料纂集 国史館日録 第三：続群書類従 完成会, 84

16）少焉相公対面，命郷導者令我輩遊歩後園，過林登山，繞池超橋，移刻 入池亭, 相公在焉, 先進膳, 而談本朝通鑑之事…… 山本武夫校訂（1997）：史料纂集 国史館日録 第四： 続群書類従 完成会, 8

17）余以異邦橒朽，倚萧蒦於玉樹之藩。轉落英之曲逕，經臥波之長橋。争 妍競艶，目炫心招。(中略)余覧天下之名園多矣。……斯園殆甲於天下 矣

朱舜水 (1669) : 遊後楽園賦并序：朱舜水集巻十二（1981）：中華書 局, 429

18）於是盤磴道, 臨幽壑。度鵲橋, 登飛閣。…...铅然改観, 意気軒々。…... 重霄饗答，下瞰干門。其為楽也融々，豈復有加於此者哉？ 前掲書 17), 429

19）諸橋䡴次（1960）：大漢和辞典 巻二 : 大修館書店, 530

20）舟子艤船橋畔，扶掖而登。睇望丹丘，溯洄三市，曰：「余吳人也，我 歌子和，戯唱呉歈以相獹可乎？」哈曰「可哉」。因為棹歌行曰：泉源 滺々, 桂楫松桴, 水安流兮, 橈櫂輕揉。天生民而立之君, 天生水而作 之舟，堯與禹憂労天下，到于今，到于今，載明徳也悠々。」舟中之人， 撫掌大笑。遙指疊憉謂是人為。又為之歌日：「天作高山, 人之力可以 擬之。已百已千，維其喜之。巍々其有成功，夫誰止之?」 前掲書 17)，430

21）諸橋䡶次（1960）：大漢和辞典 巻七：大修館書店, 1143

22）吉永義信（1937）：小石川後楽園(名勝調査報告第三輯）：文部省，10

23）額賀信興（1736）：後楽園記事：東京市史稿 遊園篇第一（1929）： 東京市役所, 133

24）吉永義信（1938）：後楽園雑考：造園研究 第二十五輯，14

25）田村剛（1938）：後楽園の意匠：造園研究 第二十五輯，3

26）太田元貞 (1794) ：遊後楽園記：東京市史稿遊園篇第三:東京市役所, 574

27）（前略）於是優遊盤桓，尋壀経丘；踞䉷畔以憑木，攀薛羅而登楼。西 望市塺，往来絡繹；南仰金城，雉堞㟊喍。指左顧右，遊目騁懐。浩浩 焉, 漂漂焉, 於乎所遊絶勝之地, 而所楽一生之尤也, 非特極耳目之娛 而已

人見傳(1669)：春遊小石川邸後楽園記：朱舜水集付録三（1981）：中 華書局, 770

28）清水の堂立たる山は高さ六七丈，(中略)蛇籠をも置きつづたる風景, さながら大井川嵐山の古き跡みる心ちなれや，松の葉ごしに富十のみ ゆる計にて，外には目にさはる者むなきのみや，此御庭の絶景にして， 西山侯の御自稱なりしとか，折節ふじの晴れてみゆれば，富士の称を 松の葉ごしに見渡せば，三保の浦浪扔あかげにたつなどと申すてたる 御庭む今はみる事を禁ぜらるるのみか，両度まで炎上せしかば，何事 あ古き世のみとはよく書たる事よ,

辻雪洞（1692）：東都紀行：新燕石十種第二（1941）：廣谷国書刊行 會, 283 